\title{
Rekreatif Gruplara Üyelik: Motosiklet Grupları Üzerine Bir İnceleme*
}

Membership in Recreational Groups: An Investigation on Motorcycle Groups

\author{
Mehmet ERTAŞ**, Gürhan AKTAŞ*** \\ **Arş. Gör. Dr., Pamukkale Üniversitesi, Turizm Fakültesi, Turizm İşletmeciliği Bölümü, Kınıklı Kampusu, 20160 Pamukkale, Denizli. \\ E-posta: mehmetertas@pau.edu.tr \\ ORCID No: 0000-0003-4396-5104 \\ ***Doç. Dr., Dokuz Eylül Üniversitesi, İşletme Fakültesi, Turizm İşletmeciliği Bölümü, Kuruçeşme Mahallesi, Dokuz Eylül Üniversitesi, Kaynaklar Yerleşkesi, 35390 \\ Buca, İzmir. \\ E-posta: gurhan.aktas@deu.edu.tr \\ ORCID No: 0000-0003-2392-5930
}

MAKALE BILGILERI

Makale işlem bilgileri:

Gönderilme tarihi: 6 Haziran 2018

Düzeltme: 27 Temmuz 2018

Kabul: 5 Eylül 2018

Anahtar sözcükler: Rekreatif gruplar, Grup üyeliği, Motosiklet grupları, Motosiklet kullanicuları.

\section{ARTICLE INFO}

Article history:

Submitted: 6 June 2018

Resubmitted: 27 July 2018

Accepted: 5 September 2018

Key words: Recreational groups, Group membership, Motorcycle groups, Motorcycle users.

\section{ÖZ}

İnsanlar yaşamları boyunca, aile, arkadaş ve benzeri grupların içinde olma gereksinimi duymaktadır. İnsanlar zorunlu olarak içinde oldukları bu grupların yanında serbest zamanlarını geçirdikleri ve gönüllü olarak katıldıkIarı rekreatif gruplara da üye olmaktadır. Bu çalışmanın amacı, kişilerin gönüllü olarak katıldıkları motosiklet gruplarına üyeliğin nedenlerinin incelenmesidir. Bu kapsamda, çalışmanın birincil verileri aktif olarak motosiklet kullanan 27 kişi ile yüz yüze görüșmeler aracılığıyla toplanmıștır. Çalışmada nitel araștırma yöntemlerinden olan olgu bilim (fenomenoloji) deseni kullanılmıștır. Verilerin analizinde ise içerik analizi tekniğinden yararIanılmıştır. İçerik analizi sonucunda motosiklet gruplarına üyeliği etkileyen etmenlerin yedi ana kategoride toplandığı görülmüştür. Bu kategoriler; güvenlik, sosyalleşme, tecrübe kazanma, deneyim paylaşma, eşitlik, grubun gücü ve grup kurallarıdır. Sonuç olarak, motosiklet kullanıcıları seyahatlerinde kendilerini güvende hissetmek, grup içinde farklı insanlarla tanıșmak, deneyimli kișilerden tecrübe kazanmak ve seyahatleri sırasında tek başlarına yaşayamayacakları deneyimleri grup ile birlikte yaşayabilmek için motosiklet gruplarına üye olmaktadır. Motosiklet grupları üzerine yapılan bu inceleme çalıșmasının, bireylerin rekreatif gruplara katılımlarını etkileyen etmenlerin ortaya çıkarılmasını amaçlayarak, rekreatif gruplarda gönüllü grup üyeliği konusundaki gelecek çalışmalara örnek teşkil etmesi umulmaktadır.

\section{ABSTRACT}

People need to be part of various groups such as family and friends, throughout their life. In addition to these almost obligatory groups, people also voluntarily join recreational groups, with which they socialize during their spare time. The aim of this research is to investigate the reasons why members join a specific recreational group: motorcycle groups. To this end, the primary data is collected from 27 motorcycle users with face-to-face interviews. As a qualitative study, the research uses a phenomenological design and it employs the content analysis. According to the findings, the factors influencing motorcycle group membership are split into seven categories: safety, socialization, experience, experience share, member equality, group power and group rules. In other words, motorcycle users become members to their recreational groups in order mainly to feel safe during their trips, to meet with other members, to benefit from the guidance and support offered by the experienced members and to enrich their experiences as a group, which could not be achieved as individuals. The research conducted on motorcycle groups is, therefore, hoped to become an exemplar to further research on voluntary membership to recreational groups, through its attempts to identify the attributes of recreational group membership.

\section{GíRiş}

Gelişen toplum yaşantısı içinde insanların refah düzeyi yükselirken sanayileşme ve kentleşmeye

\footnotetext{
* Bu makale, 5-8 Nisan 2018 tarihleri arasında Kıbrıs'ta düzenlenen 9. Lisansüstü Turizm Öğrencileri Araştırma Kongresi'nde özet olarak sunulan ve bildiri kitabında özet olarak yayınlanan "Rekreatif Gruplara Üyelik ve Grup Üyeliğinin Devamlılığı: Motosiklet Grupları İncelemesi" başlıklı bildirinin geliştirilmiş halidir.
}

bağlı olarak artan iş temposuyla birlikte toplum içinde insanlar yalnızlaşmaya başlamışlardır. Bununla birlikte, sanayinin gelişmesiyle otomasyon sistemlerinin kullanımının artması insanların çalışma saatlerinin azalmasını, sosyal haklarının artmasını ve ücretli izin kullanımının yaygınlaşmasını sağlamış ve bunların sonucunda insanların serbest zamanları artmıştır (Karaküçük 2008). Insanlar aile adı verilen bir grup içinde dünyaya 
gelir ve bu gruba üyeliği sayesinde yaşamına devam eder. Doğası gereği sosyal bir varlık olan insan fizyolojik olduğu kadar sosyal gereksinimlerini de karşılama niyetindedir (Johnson ve Johnson 2014). Günlük yaşantımızın büyük çoğunluğunu başta aile olmak üzere arkadaş grubu, meslek grubu vb. gruplar oluşturmaktadır. $\mathrm{Bu}$ grupların yanı sıra insanlar, sosyalleşmek amacıyla serbest zamanlarını aktif ve eğlenceli bir şekilde geçirdikleri, yeni arkadaşlıklar edindikleri ve paylaşım içinde oldukları, özel ilgi gruplarından olan rekreatif grupların içine de dâhil olmaktadır. Bu katılım kimi zaman geçici süreli olurken kimi zaman ise rekreatif bir gruba üyelik ile kalıcı hale gelmektedir.

İnsanlar, sosyal bir varlık olarak başkaları ile birlikte çalışmaya veya birlikte hareket etmeye eğilimlidirler (Allen ve Donnelly 1985). Bir gruba üye olan kişiler, gruba üye diğer kişilere yardım etme konusunda daha fazla istek göstermektedirler ve kendi grubu dişındakilerden ziyade grup içindeki üyelere dayanışma ve sosyal destek sağlamaktadırlar (Hornstein 1972). Grup üyeleri bazı durumlarda dâhil oldukları gruplar için hayatlarını tehlikeye atacak konuma dahi gelebilmektedir (Swann vd. 2012). Kismen bu durumun sebebi, grup üyeliğinin sosyal destek veya yalnızlık gibi gruba bağlantılı yapılardan daha güçlü ve daha dayanıklı bir şekilde sosyal bağlılığın belirginleşmesini sağlamasıdır (Cruwys vd. 2013).

Alanyazında grup çalışmaları, grup içi etkileşimleri gözlemleme ve gruplar arası çatışmalar (Sherif 1936), gruplar arası ayrımcılık (Tajfel 1970), grup içinde sosyal sınıflama (Tajfel 1981) ve gruplar içinde sosyal kimlik (Tajfel 1978) gibi konulara odaklanmıştır. Sosyal grup üyeliği üzerine yapılan çalışmalar ise sosyal grup üyeliğinin depresyona etkisi (Cruwys vd. 2013), sosyal grup üyeliğinin stresle başa çıkmaya etkisi (Haslam vd. 2004), kişinin sosyal grup içindeki statüsünün üyeliğe etkisi (Anderson vd. 2001), sosyal grup üyeliğinin kişinin sağlığına etkisi (Haslam vd. 2008; Haslam vd. 2009) ve kişinin sosyal gruplara aitlik hissi (Newman vd. 2007) gibi konular üzerine odaklanmıştır. Yukarıda da görülebileceği üzere, bugüne kadar yapılan çalışmaların büyük bir çoğunluğu grup içindeki bireye, diğer bir deyişle bireylerin gruplardan kazanımlarına odaklanmaktadır. Rekreatif gruplar ve bu gruplara katılan kişilerin grup olarak ele alındığı çalışmalar oldukça sınırlıdır. Motosiklet ile seyahat eden bireyler üzerine yapılan araştırmalar kişilerin bireysel güvenlik ve yaşadıkları kazalar üzerine odaklanmaktadır (Mannering ve Grodsky 1995; Clarke vd. 2007). Bu çalışmanın konusunu oluşturan kişilerin motosiklet gruplarına üyelikleri üzerine yeterli sayıda çalışma bulunmamaktadır. Bu doğrultuda, bu çalışmanın amacı rekreatif bir grup olarak motosiklet gruplarına katılan ve aktif olarak grupla seyahat eden bireylerin motosiklet grubuna katılım ve üyeliklerinin nedenlerini ortaya çıkarmaktır. Bu açıdan çalışmanın, diğer rekreatif gruplar açısından gruba üyelik ve grupla seyahat etme eğilimleri üzerine yapılacak çalışmalara örnek teşkil edeceği düşünülmektedir.

\section{KAVRAMSAL ÇERÇEVE}

Bu bölümde, grup üyeliği ve rekreatif gruplara yönelik çalışmalar ışığında çalışmanın kavramsal çerçevesine yer verilmektedir. Rekreatif gruplara üyelik konusunda az sayıda çalışma olması nedeniyle, bu bölümde öncelikle rekreasyon kavramina daha sonra grup üyeliği ve grup üyeliğinin nedenleri ele alınmış, rekreatif grup tanımı ve bu gruplara üyelik konusu irdelenmiştir.

\section{Grup Üyeliği}

Grup, kendilerini bir gruba ait olarak algılayan, birbirine bağımlı ve birbirini etkileyen iki veya daha fazla kişinin bazı gereksinimlerini karşılamak ve aynı hedefe ulaşmak için oluşturduğu sosyal birim olarak tanımlanmaktadır (Sherif 1967; Turner 1987; Forsyth 2009; Johnson ve Johnson 2014). Üyelerine güvenlik sağlamak, ekonomik faaliyetlerde bulunmak, sosyal deneyimler için fırsatlar sağlamak, gençleri eğitmek veya binlerce farklı hedefe ulaşmak için grup kurulabilir (Coleman 1969). Gruplar, tesadüfi olarak bir araya gelmiş bireylerden oluşmamaktadır, aksine kolektif olarak bir araya gelmiş, grup üyelerini kuşatan kişisel ilişkilere dayanmaktadır (Forsyth 2009). 
İnsanların dâhil olduğu gruplar, refah düzeyini, eğitim durumunu, konuştuğu dili, tutumunu ve benimsediği kültürel pratiklerini ve kim olduğunu belirler (Hogg ve Vaughan 2007). Aynı zamanda bu gruplar, kişinin refahı için olumlu etkilere sahiptir ve bireylerin yaşam boyunca karşılaştıkları geçişlere uyum sağlamada önemli bir rol oynamaktadır (Reicher ve Haslam 2006). Bu geçişlerin olumlu olması, yüksek statüde, saygin bir organizasyona veya arzu edilen bir gruba geçmeyi içermektedir ve değişimin kendisinin yarattığı olumsuz sonuçlara karşı kişinin benlik saygısı için olumlu etkiler yaratmasına yardımcı olmaktadır (Haslam vd. 2008). Bu durum, grup üyelerinin diğer grup üyelerini, birbirleriyle kurdukları kişisel ilişkiler açısından değil, grup üyeliği merceğinden algılayacağı anlamına gelmektedir (Swann vd. 2012).

İnsanlar çoğu zaman gönüllü olarak ve isteğe bağlı üye oldukları grupların kendileri için önemli değerler taşıdığını düşünmektedir ve kendileri için değerli bu grup üyeliğinden vazgeçmek konusunda isteksiz davranmaktadır (Swann vd. 2012). Grup üyeliklerinin daha düşük statüye sahip olduğunun algılanması halinde ise gruba üye olmaya yönelik direnç artmaktadır ve kişiler daha yüksek statüdeki gruplara üye olma eğilimi göstermektedir (Van Knippenberg vd. 2002). Kişinin gruptaki konumu, üyelerin grup içinde birbirlerine olan davranışları, kişinin geleceğe ilişkin kararları ve özsaygısı gibi faktörlerden etkilenebilmektedir. Bu nedenle kişi için grup üyeliği çok çekici olabileceği gibi çok s1kıcı sorunlar da yaratabilir.

Gruplar içinde yaşamak kişinin benlik olma duygusundan gelmektedir ve kişinin grubu içselleştirmesinden kaynaklanmaktadır (Haslam vd. 2008). Grup üyeliği insanlara sosyal bir kimlik vermektedir (Broughton ve Walker 2009). Turner ve arkadaşları (2006) grup üyeliğinin hem sosyal hem de kişisel kimliklerin temelini oluşturduğunu ve her zaman kolaylıkla ayrilabilir nitelikte olmadığını ileri sürmektedir. İnsanın kişiliğinin oluştuğu yerler onun kültürel, eğitsel ve duygusal yaşamı üzerinde büyük etkiler yapan inanç ve tutumlarını biçimlendiren, üyesi olduğu gruplardır (Eren 1989). Etnik köken, sosyo- ekonomik durum, eğitim durumu, kültür, ırk ya da diğer özelliklerden bağımsız olarak, bireyler kendi amaçlarına, tercihlerine ve ilgi alanlarına dayalı olarak grup faaliyetlerinde yer almaktadır (Kim 2012).

\section{Rekreatif Gruplar}

Rekreasyon, insanın kişiliğine uygun olarak yapmaktan keyif aldığı sosyal, kültürel ve sportif etkinliklere katılmak, başka insanlarla etkileşmek, günlük yaşamın sıkıcılığından kurtulmak ve toplumsal bir kişilik kazanmak için yaptığı faaliyetler bütünü olarak tanımlanmıştır (Bucher ve Bucher 1974). Başka bir tanımda ise rekreasyon, insanın yoğun çalışma yükü, monoton hayat tarzı veya negatif çevresel etkilerden olumsuz etkilenen beden ve ruh sağlığını tekrar kazanmak, koruyarak devam ettirmek, haz almak, kişisel doyum sağlamak amacıyla gönüllü olarak ferdi veya bir grupla gerçekleştirdiği serbest zaman etkinlikleridir (Karaküçük 2008). Son olarak Tütüncü (2012: 249) ise rekreasyonu "insanın yaşam kalitesini artırmak için serbest ve boş zamanında doğaya zarar vermeden, kendi istemi ve gönüllü olarak yaptığı faaliyetleri kapsayan multidisipliner bir çaıışma alanı" şeklinde tanımlamıştır. Yapılan bu tanımların ışığında rekreasyon, insanların para kazandıkları çalışma hayatlarının dışında kalan serbest zamanlarında gönüllülük esasına dayalı olarak mutluluk, keyif, haz, kendini gerçekleştirme, doyum vb. gibi gereksinimlerini karşılamak için katıldıkları aktiviteler olarak tanımlanabilir.

İnsanlar, monoton ve sosyal olmayan hayatlarindan rekreasyon uygulamaları sayesinde kurtulmaktadır. Girdikleri sosyal ortamlarda diğer insanların sahip olduğu inanç ve düşünceler etkilenmekte bunun sonucunda ise insanların alg1 düzeyi artarak olumlu kazançlar elde etmesini sağlamaktadır (Atalay vd. 2013). Bu amaçla dışarıdaki alanlarda gerçekleştirilen bisiklet sürme, doğa yürüyüşü ve kayak yapma vb. etkinlikler kişinin sosyal ortamda başka insanlarla tanışmasına ve temiz havada gerçekleştirildiğinden insan sağlığına olumlu etkiler sağlamasına olanak tanımaktadır (Tütüncü ve Aydın 2014). Aynı zamanda bu rekreasyon etkinlikleri kişileri yoğun, 
yorucu ve stresli hayatlarından uzaklaştırarak zihinsel ve fiziksel sağlıklarının yeniden toparlanmasına yardımcı olmaktadır (Tel ve Köksalan 2008). Bu rekreasyon etkinlikleri; grup ya da bireysel olarak, aktif veya pasif bir biçimde katılım sağlanan spor, gezi, eğlence kültürel etkinlik ve benzeri aktiviteleri kapsamaktadır (Can 2015).

Rekreasyon uygulamalarının kişinin zihinsel ve fiziksel yapısına yararları olduğu gibi rekreatif gruplar aracılığıyla sosyo-kültürel faydaları da vardır. Kişinin ağırlıklı olarak katıldığı sosyal grupları anlamaya çalışmak, insanların boş zaman davranışlarını kısmen açıklayabilmektedir (Allen ve Donnelly 1985). Grup halinde yapilan rekreatif faaliyetlerde insanlar birlikte bir takım olarak hareket etmeyi, sorumluluk ve risk almayı öğrenmektedir (Tütüncü ve Aydın 2014). Ayrıca grup rekreasyon faaliyetleri, sosyal bir varlık olan insanı iç dünyasında kendisi ile barışık, dışa dönük, mutlu ve verimli hale getirmektedir (Yağmur ve Tarcan-İçigen 2016).

\section{YÖNTEM}

Araştırmanın amacına yön veren ana çerçeveyi belirlemek ve bu doğrultuda uygun soruları geliştirmek için alanyazın taraması yapılmıştır. Alanyazın taraması kapsamında sosyal grup çalışmaları ve rekreatif gruplar üzerine yapılan çalışmalara odaklanılmıştır. Rekreatif gruplara üyelik üzerine herhangi bir çalışmaya rastlanılmamış olmasından dolayı grup üyeliği ve sosyal gruplar üzerine yapılan çalışmalara odaklanılmıştır. Öncelikle alanyazındaki grup üzerine yapılan çalışmalar (Sherif 1936; Tajfel 1970; Tajfel 1981; Tajfel 1978), daha sonra sosyal gruplar üzerine yapılan çalışmalar incelenmiştir. Bu incelemeler neticesinde, araştırma sorularının geliştirilmesi aşamasında, farklı rekreatif gruplara üyelik sürecinin, grupları bir araya getiren temel rekreasyon faaliyeti, grup kuralları ve üyelerin demografik ve sosyo-kültürel özellikleri gibi pek çok faktör ışığında şekillendiği ve gruplara üyelik gerekçelerinin farklılık gösterebileceği varsayılmıştır (Anderson vd. 2001; Haslam vd. 2004; Haslam vd. 2008; Cruwys vd. 2013). Sonuç olarak, alanyazındaki çalışmalara paralel olarak araştırmanın iki temel sorusu ortaya çıkmıştır.
1) Motosiklet gruplarına üye olmanın nedenleri nelerdir?

2) Motosiklet gruplariyla seyahat etmenin nedenleri nelerdir?

Araştırmada kullanılan birincil verilerin toplanmasında ve analizinde, Guba'nın (1981) nitel araştırmalar için geliştirdiği güvenirlik, aktarılabilirlik, tutarlılık ve doğrulanabilirlik temel ölçütleri çerçevesinde geliştirmiş olduğu "güvenirlik modeli" temel alınmıştır. Bu doğrultuda görüşmelerde katılımcıların verdiği cevapların gerçekliğinin doğrulanması açısından bazı sorular tekrar sorulmuştur (Shenton 2004). Çalışma nitel araştırma desenlerinden biri olan olgu bilim (fenomenoloji) yaklaşımı üzerine kurulmuştur. Bir konuyu derinlemesine anlamak ve öğelerini kapsamlı bir şekilde ortaya koymak (Patton 2002) amacıyla yarı yapılandırılmış soru formuyla görüşmeler yapılmıştır. Görüşmelere temel teşkil eden ve alanyazın araştırması sonucu geliştirilen soru formları, rekreasyon alanında çalışmaları bulunan akademik uzmanların görüşüne sunulup, onaylandıktan sonra araştırmanın temel iki sorusunun detaylandırıldığı ve alt başlıklarının belirlendiği son şeklini almıştır. Ancak, görüşmeler sırasında farklı motosiklet kullanıcılarının kendi deneyim ve birikimleri ışı̆ında sundukları bilgiler doğrultusunda görüşme esnasında da anlık sorular ile veri toplama süreci yürütülmüştür.

Araştırma kapsamında görüşme yapılacak kişiler, araştırma örnekleminin motosiklet gruplarından oluşması nedeni ile kartopu örnekleme yöntemi ile belirlenmiştir. Görüşme yapılan birinci kişi amaçlı örneklem doğrultusunda belirlenmiş ancak araştırmanın güvenirliği ve geçerliği aç1sından veri analizinin içine alınmamıştır. Görüşmeler sırasında ilk önce araştırmacı kendini tanıtmış ve çalışmanın amacını belirttikten sonra görüşmeye başlamıştır. Görüşmeler, 03.07.201709.12.2017 tarihleri arasında motosiklet grubuna aktif olarak üye olan ve grupla birlikte seyahat eden 27 motosiklet kullanıcısıyla gerçekleştirilmiştir. Görüşme sırasında elde edilen cevapların tekrarlamaya başladığ 20 . görüşmeden sonra veri toplama süreci yedi kişi ile daha devam ettirilmiş, yeni bir veri elde edilmediği ve doygunluk noktasına ulaşıldığı anlaşılmıştır. Nitel çalışma- 
larda maksimum çeşitlilik ile beş ila 25 arasında görüşmenin yeterli olacağını belirtildiğinden, 27 görüşme ile veri toplama süreci tamamlanmıştır (Creswell 1998). Görüşmeler 47 ila 110 dakika arasında sürmüştür ve tüm görüşmelerin ortalaması ise 76 dakikadır. Görüşmeler yapılmadan önce motosiklet ile seyahat eden kişiler aranarak uygun oldukları gün ve saatler için randevu alındıktan sonra görüşmeler yapılmıştır.

Görüşmeler, katılımcıların izni dâhilinde ses kayıt cihazı ile kayıt altına alınarak bilgisayar ortamında yazıya aktarılmıştır. Görüşme yapılan motosiklet kullanıcıların isimleri gizli tutulmuş $\mathrm{K} 1, \mathrm{~K} 2, \ldots, \mathrm{K} 27$ şeklinde katılımcı sayıları ile belirtilmiştir. Verilerin analizinde içerik analizi tekniği kullanılmıştır. Bu kapsamda içerik analizinde Strauss ve Corbin (1990) tarafından önerilen model temel alınarak gerçekleştirilmiştir. Bu model, iki uzman tarafindan kodlamanın yapılmaSı, ortak kategorilerin ortaya çıkarılması, verilerin ana kategori ve alt kategori olarak ayrılması, verilerin yorumlanması ve son olarak verilerin değerlendirilmesi olarak beş aşamadan oluşmaktadır. Merriam da (2013) içerik analizini, anahtar sözcük olarak bir metin içindeki mesajların kategoriler oluşturmasını içerdiğini belirtmektedir. Bu bilgiler 1şığında görüşmeler sonucunda elde edilen içerik analizi sonuçlarının doğrulanması amaciyla aktif olarak motosiklet grubuna üye kişilere bulgular tekrar gönderilmiş ve içerik analizinin geçerliği sağlanmıştır (Shenton 2004). Bulguları daha iyi anlamak ve verilerin güvenirliğini arttırmak için görüşmelerden elde edilen doğrudan alıntılara bulgular kısmında yer verilmiştir.

\section{BULGULAR}

Bu bölümde aktif olarak motosiklet gruplarına üye olan ve seyahat eden kişilerle görüşmelerden elde edilen verilere yer verilmiştir. İlk olarak çalışmada yer alan katılımcıların demografik özelliklerine yer verilmiştir. Tabloya göre görüşme yapılan kişilerin büyük bir çoğunluğunun 18-50 yaş aralığında olduğu (yüzde 88), beş yıldan fazladır aktif olarak motosiklet kullandığg (yüzde 74), dört yıldan fazladır motosiklet grubuyla seyahat ettiği (yüzde 70) ve grupla birlikte yılda 10 seferden fazla seyahat ettiği bulunmuştur (yüzde 78).

Görüşmeler sonucunda elde edilen verilen içerik analizi sonuçları Tablo 1'de gösterilmektedir. Buna göre aktif olarak motosiklet kullanan kişilerin grupla seyahat etme nedenleri yedi ana kategori ile 34 alt kategori altında toplanmıştır.

Görüşmeler sonucunda ilk ana kategori, güvenlik olarak ortaya çıkmıştır. Motosiklet kullanıcilarının bir grubuna üye olmalarının en temel nedeni, uzun seyahatlerde karşılaşacakları herhangi bir olumsuz durum karşısında yanlarında birinin olacak olması sebebiyle kendilerini güvende hissetmektir. Sürüş esnasında motosiklet kullanıcısının yanında ona yardım edecek birinin olması ve onu ne sebep olursa olsun yalnız bırakmayacağını bilmesi kişiye güven duygusu vermektedir. Motosiklet kullanıcıları seyahat s1rasinda motosikletlerinin bozulması, lastiklerinin patlaması, önemli bir kaza yaşanması vb. durumlarda grup içinde olmanın daha güvenli olduğunu belirtmişlerdir. Ayrıca, grup içinde sürmek diğer trafik araçlarının oluşturacağı dışarıdan gelebilecek tehlikeleri de en aza indirmektedir. Grup sürüşünde yol kaptanı ve artçı gibi güvenliği sağlayan kişilerin olması daha güvenli sürüş yapılmasını sağlamaktadır. Bu kişiler sürüş esnasında güvenliği sağladıkları gibi herhangi bir olumsuz durumda örneğin grup içindeki bir üyenin motosikletinin arızası durumunda kişinin yanında kalarak sorununun çözülmesine yardımcı olmaktadır.

Ana kategorilerden ikincisi sosyalleşme olarak ortaya çıkmıştır. Bir gruba üye olmadan önce monoton ve sosyal olmayan bir hayata sahip motosiklet kullanıcıları motosiklet gruplarına girdikten ve onlarla seyahat ettikten sonra daha fazla sosyalleşme olanağı bulmaktadırlar. Motosiklet kullanıcıları kendileriyle aynı tutkuya sahip kişilerle motosiklet deneyimini yaşamanın daha keyifli olduğunu belirtmişlerdir. Ortak amaç ve hedefleri bir araya getirmek için gruba üye olan motosiklet kullanıcıları grup içinde olmayı yeni arkadaşlıklar ve dostluklar edinmenin bir yolu olarak görmektedirler. Bu gruplar aynı zamanda oldukça aktif gruplar olduklarından daha fazla etkinlik düzenlemekte ve daha fazla yere seyahat 
Tablo 1. Görüşmelerle İlgili Bulgular

\begin{tabular}{|c|c|c|}
\hline Ana & Alt Kategori & Örnek Alıntılar \\
\hline \multicolumn{3}{|l|}{ Kategori } \\
\hline \multirow[t]{5}{*}{ Güvenlik } & Kaygıda azalma & $\begin{array}{l}\text { Dalış yaptığınızda yanınızda body olmadan olmaz. Motosiklette de aynı } \\
\text { şekildedir. Yanında birinin olması seni güvende hissettiriyor (K17). }\end{array}$ \\
\hline & Kaza ve arızalarda yardım & $\begin{array}{l}\text { Yolda lastiğiniz patlayabilir, ufak bir kaza yapabilirsiniz. Herhangi bir } \\
\text { şekilde yardıma gereksinimiz olduğunda yanınızda en az bir arkadaşınız } \\
\operatorname{var}(\mathrm{K} 5) \text {. }\end{array}$ \\
\hline & Dışsal faktörleri azaltma & $\begin{array}{l}\text { Normalde bir araç sürücüsü tek giden motosikletin dibinden geçer ama } \\
\text { toplu sürüyorken bayağı bir uzağında sürüyor (K12). }\end{array}$ \\
\hline & Güvenliği sağlayıcıları & $\begin{array}{l}\text { Grubu sağlıklı bir şekilde tek parça gideceği yere varış noktasına } \\
\text { götürebilmek için grup içinde herkesin birtakım görevleri var (K10). }\end{array}$ \\
\hline & Dikkati koruma & $\begin{array}{l}\text { Grup sürüşü olduğu zaman dikkatimizi korumamıza yardımcı oluyor daha } \\
\text { iyi odaklanabiliyoruz (K16). }\end{array}$ \\
\hline \multirow[t]{5}{*}{ Sosyalleşme } & Yalnızlıktan kurtulma isteği & $\begin{array}{l}\text { Şu an sistemin dayattığı toplumsal bunalımı o yalnızlığı grup içinde yok } \\
\text { edebiliyorsunuz (K18). }\end{array}$ \\
\hline & Yeni arkadaşlar edinme & $\begin{array}{l}\text { Gruba girdikten sonra yeni arkadaşlarınız oluyor. Onlarla keyifli ve hoş } \\
\text { sohbetler gerçekleştiriyorsunuz (K16). }\end{array}$ \\
\hline & Keyifli vakit geçirme & Bu uzun yol yolculuklarını grupla yapmak her zaman daha keyiflidir. (K15) \\
\hline & Etkinliklere katılma & $\begin{array}{l}\text { Hafta sonu ben bir yere çadır atmaya kamp yapmaya gidiyorsam } \\
\text { muhakkak grupla giderim (K19) }\end{array}$ \\
\hline & Yeni yerler görme & $\begin{array}{l}\text { Motosiklet grubunda daha fazla yeni yer görüyorum, daha fazla seyahat } \\
\text { ediyorum, gitmediğim yerlere gidiyorum (K21) }\end{array}$ \\
\hline \multirow[t]{4}{*}{$\begin{array}{l}\text { Tecrübe } \\
\text { kazanma }\end{array}$} & Sürüş deneyimi & $\begin{array}{l}\text { Bu gruba tecrübe kazanmak, grup içindeki kişilerle yol yapıp sürüşümü } \\
\text { geliştirmek için girdim (K26). }\end{array}$ \\
\hline & $\begin{array}{l}\text { Mekanik (motosiklete özgü) } \\
\text { bilgi öğrenme }\end{array}$ & $\begin{array}{l}\text { Motosikletlerle ilgili yeni çıkan motorlarla, motorun teknik özelliklerle grup } \\
\text { içinde işi iyi bilen birisinden tekniğini öğreniyorsun (K9). }\end{array}$ \\
\hline & Sürüş eğitimleri & $\begin{array}{l}\text { Türkiye'nin en iyi eğitmenlerinden eğitim almak gibi zorunluluğumuz var. } \\
\text { Grup içindeki her üyemize bu eğitimi aldırııı (K22). }\end{array}$ \\
\hline & $\begin{array}{l}\text { Yeni rotalar keşfetme ve } \\
\text { öğrenme }\end{array}$ & $\begin{array}{l}\text { Hiç görmediğim ve duymadığım yerler hakkında bilgi alabiliyorum. Yeni } \\
\text { rotaları, yolları öğreniyorum (K21). }\end{array}$ \\
\hline
\end{tabular}


Tablo 1. Görüşmelerle İlgili Bulgular (Devam)

\begin{tabular}{|c|c|c|}
\hline \multirow[t]{6}{*}{$\begin{array}{l}\text { Deneyim } \\
\text { paylaşma }\end{array}$} & Aynalama & $\begin{array}{l}\text { Motosiklete bindiğin zaman kendini görmüyorsun ama yanında senin } \\
\text { benzerin bir başka bir motosikleti seyretmek de ayrı bir zevk verir. } \\
\text { Yanındaki motosikletler ile aynı hareketleri yapmak aynalama } \\
\text { oluyorsun (K4). }\end{array}$ \\
\hline & Anı fotoğraflama & $\begin{array}{l}\text { Beş motor arka arkaya gittiğinizde, dışarıdan bakıldığında toplu sürüşün } \\
\text { fotoğrafı çok güzel görünür (K16). }\end{array}$ \\
\hline & Toplu sürüş deneyimi & $\begin{array}{l}\text { Grup içindeki arkadaşlarımla bir şeyi paylaşmak ortak hareket etmek } \\
\text { güzeldir. İçtiğinizi, yediğinizi, sürüşü paylaşırız (K6). }\end{array}$ \\
\hline & Topluluk içinde olma isteği & $\begin{array}{l}\text { İnsan yaradılış itibariyle doğayla baş edebilmek, zor zamanında bir fayda } \\
\text { sağlamak ve kendini güvende hissetmek için topluluk halinde yaşamak } \\
\text { ister. Sadece bu güdü ve yaklaşım insanları motosikletlere ve özellikle grup } \\
\text { halinde sürmeye güdüler (K4). }\end{array}$ \\
\hline & Ortak hareket etme isteği & Birlikten kuvvet doğar mantığıyla ortak hareket ederiz (K17). \\
\hline & Gruba uyum & $\begin{array}{l}\text { Yolda giderken motosikletlerin tek bir parça gibi hareket etmesi } \\
\text { gökyüzündeki kuşlar gibidir (K7). }\end{array}$ \\
\hline \multirow[t]{2}{*}{ Eşitlik } & Her kesimden insanın olması & $\begin{array}{l}\text { Bu gruba girerken belli bir kıstas yok, şöyle olmak zorundasın böyle olmak } \\
\text { zorundasın gibi bir kıstas yok (K15). }\end{array}$ \\
\hline & $\begin{array}{l}\text { Motosiklet fiziksel yapısının } \\
\text { önemsizliği }\end{array}$ & $\begin{array}{l}\text { Grup içinde motosiklet ayrımı olmuyor, her motosiklet türünü kullanan } \\
\text { vardır (K13). }\end{array}$ \\
\hline \multirow[t]{7}{*}{$\begin{array}{l}\text { Grubun } \\
\text { gücü }\end{array}$} & Kulübün tanınırlığı & $\begin{array}{l}\text { Atıyorum yeleğinizi giydiniz yolda başka motosikletçilerle karşılaştınız bak } \\
\text { bunlar şu motosiklet grubu, arması var üzerinde diyor (K20). }\end{array}$ \\
\hline & Saygınlık kazanma & $\begin{array}{l}\text { Dışarıdaki insanlar bu bir grubun üyesi deyip daha saygılı olma gereksinimi } \\
\text { güdüyor (K27). }\end{array}$ \\
\hline & Her yerde üyesinin olması & $\begin{array}{l}\text { Bir motosiklet grubuyla takılmaya başladığın zaman her yerde bir } \\
\text { tanıdığınız olabiliyor (K13). }\end{array}$ \\
\hline & Kalabalık olma isteği & $\begin{array}{l}30 \text { Ağustos Zafer Bayramı'nda Dumlupınar Şehitliği'nde kamp kuruyoruz. } \\
\text { Orada katıım olursa iyi olur deniliyor, ne kadar çok motosiklet olursa o } \\
\text { kadar güzel olur gibi istekler oluyor (K8). }\end{array}$ \\
\hline & Gösteriş & $\begin{array}{l}\text { 20-30 motosiklet aynı anda bir mekâna girdiğinizde insanlar size çok farkıı } \\
\text { bakıyorlar (K3). }\end{array}$ \\
\hline & Özel sürüşlere katılma, & $\begin{array}{l}\text { Şehit polisimiz Fethi Seki için kortej yaptık bin motor geldi soğuk havada } \\
\text { (K22). }\end{array}$ \\
\hline & Trafikte fark edilmek & $\begin{array}{l}\text { Grupta birlikteliğin verdiği bir güç vardır. } 20 \text { tane motosikletin trafikte } \\
\text { göreceği saygı ile bir tane motosikletin göreceği saygı aynı değil (K17). }\end{array}$ \\
\hline
\end{tabular}


Tablo 1. Görüşmelerle İlgili Bulgular (Devam)

\begin{tabular}{|c|c|c|}
\hline \multirow[t]{5}{*}{ Kurallar } & Sürüş düzeni & $\begin{array}{l}\text { Grup sürüşlerinde belli bir düzen ve belli hareketler var. Fermuar } \\
\text { sistemi vs. arkalı önlü 1-2-3'er şeklinde toplu olarak bir ekip halinde } \\
\text { uzun yolda birliği bozmadan, birbirlerini riske atmadan } \\
\text { kullanılabiliyor motosiklet. (K11) }\end{array}$ \\
\hline & $\begin{array}{l}\text { Sürüş esnasında sollama } \\
\text { yasağı }\end{array}$ & Grup içinde sollama yasaktır (K19). \\
\hline & $\begin{array}{l}\text { Tam donanım motosiklet } \\
\text { kullanma }\end{array}$ & $\begin{array}{l}\text { Kasksız motosiklet kullanmak kesinlikle yasaktır. Ayrıca tüm donanımın } \\
\text { üzerinde olacak, dizlik, ceket, eldiven, ayakkabı hepsi olmak zorunda grup } \\
\text { motosiklet sürüşünde (K25). }\end{array}$ \\
\hline & Hız limiti & Toplu sürüşlerde maksimum hız limiti vardır. (K12). \\
\hline & $\begin{array}{l}\text { Alkollü } \\
\text { kullanmama }\end{array}$ & $\begin{array}{l}\text { Gittiğimiz yerde kalmayacaksak asla alkol içilmez, sürüş esnasında asla } \\
\text { alkol alınmaz (K5). }\end{array}$ \\
\hline
\end{tabular}

etmektedirler. Bu nedenle motosiklet kullanıcıları bu gruplara üye olarak daha fazla seyahat ederek daha fazla yer görebileceklerini düşünmektedirler.

Ana kategorilerden üçüncüsü tecrübe kazanma olarak ortaya çıkmıştır. Motosiklet grupları içinde eğitimli ve sürüş anlamında deneyimli kişilerin olması motosiklet kullanıcılarını motosiklet gruplarına üye olmaya yöneltmektedir. Motosiklet kullanıcıları, sürüş esnasında genelde grup içindeki en eğitimli ve sürüş anlamında en deneyimli kişilerin güvenliği sağladığını, bu nedenle motosiklet kullanmaya yeni başlayanlar için motosiklet sürüşlerini geliştirmelerinin en doğru yolunun bir gruba katılmak olduğunu belirtmişlerdir. Aynı zamanda grup içindeki tecrübeli kişilerin daha önce yaşadıklarından elde ettiği bilgi ve deneyimlerden faydalanmak motosiklet kullanıcılarının sürüş ve yol tecrübelerini geliştirmeleri açısından önemlidir. Motosiklet kullanıcıları, daha önce hiç gitmedikleri yerleri ve hiç bilmedikleri rotaları grup içindeki tecrübeli kişilerden öğrenebilmektedirler. Motosikletlere ait mekanik bilgileri aynı şekilde grup içindeki başka bir üyeden faydalanarak öğrenebilmektedirler. Ayrıca, sürüş esnasında tecrübeli kişiler deneyimsiz kişi- leri yaptıkları hatalarından dolayı uyararak kişilerin tecrübe kazanmasına olanak sağlamaktadır.

Ana kategorilerden dördüncüsü deneyim paylaşma olarak ortaya çıkmıştır. Motosiklet kullanıcıları yalnız başına motosiklet kullanırken yapamayacakları deneyimleri grupla birlikte seyahat ederek yapabildiklerini belirtmişlerdir. Tek başlarına motosiklet kullanırken de keyif aldıklarını ancak bazı durumları gerçekleştirebilmek ve deneyimleyebilmek için grup içinde sürmenin daha keyifli olduğunu ve bu deneyimleri tek başlarına yapamayacaklarını ifade etmişlerdir. Özellikle sürüş esnasında yanındaki diğer motosikletin yaptığı hareketlerde kendini görmek ve kendi yaptığı hareketlerin aynısını yapan başka bir motosikleti izlemek motosiklet kullanıcılarına keyif vermektedir. Aynı zamanda bir grup motosikletin aynı anda yolda sürüş yapması ve o şeklin görüntüsüne hem dişarıdan hem de içeriden bakılmasının motosikletçilere oldukça haz verdiği görülmüştür. Tek vücut şeklinde birden fazla motosikletin aynı hareketleri senkronize bir şekilde yapması, sürüş anında herkesin gruba uyumlu bir şekilde sürüş yapması da görsellik açısından motosiklet kullanıcılarının keyif almasını sağlamaktadır. 
Ana kategorilerden beşincisi eşitlik olarak ortaya çıkmıştır. Motosiklet gruplarının içinde farklı gelir düzeylerinden, farklı siyasi görüşe sahip, farklı meslek sahibi ve toplumun her kesiminden insanın olduğu motosiklet kullanıcılar tarafından belirtilmiştir. Sosyal hayatlarında aynı ortamda bulunamayacakları belki de hayatları boyunca tanışamayacakları kişilerle motosiklet grubu sayesinde tanıştıklarını ve dost olduklarını belirtmektedirler. Grup içinde her kişinin aynı konumda olması ve eşit şartlara sahip olması motosiklet grubuna girmenin nedenleri arasında gelmektedir. Diğer taraftan motosiklet türleri açısından bazı gruplarda tek tip motor tipi kullanılması zorunluğu olmasına rağmen motor güçleri bakımından bir zorunluluğun olmaması ekonomik anlamda daha düşük fiyatlı motorlara sahip kişilerin de gruplara girmesine olanak sağlamaktadır.

Ana kategorilerden altıncisı grubun gücü olarak ortaya çıkmıştır. Motosiklet kullanıcıları grup ile birlikte yaptıkları sürüşlerde tek başlarına yaptıkları sürüşlere göre diğer araçların daha temkinli davrandıklarını belirtmişlerdir. Özellikle kadın motosiklet kullanıcıları trafikte kendilerini taciz eden diğer araç sürücülerinin grup içinde olduğunda kendilerini taciz edemediklerini ifade etmektedirler. Aynı zamanda motosiklet grubunun sahip olduğu grup üyeleri tarafından giyilen yelekler de grubun gücünü ortaya koymak açısından önemlidir. Grubu temsil etme amacıyla giyilen yelekler dışarıda bu insanlar kalabalıktır algısı yaratmakta ve diğer insanların özellikle trafikte daha dikkatli davranmalarını sağlamaktadır. Diğer taraftan, bazı motor gruplarının Türkiye' nin her yerinde oluşumlarının olması grup içindeki kişilerin ülkenin her yerinden insanları tanımasına olanak sağlamaktadır. Böylece grup içindeki motosiklet kullanıcılarının sosyal çevresi ülke çapında genişlemektedir. Ülkenin herhangi bir şehrinde bir şeye gereksinim duyulduğu zaman da o şehirde yaşayan grup üyeleri aracılığıyla işlerini kolayca çözüme kavuşturabilmektedirler. Ayrıca, özel sürüşlerde (29 Ekim korteji, 10 Kasım korteji, vb.) ve motosiklet kullanıcıları için farkındalık yaratılacak sürüşlere grup olarak katılarak duyarlı sürücüler olduklarını göstermeye çalışmaktadırlar.
Ana kategorilerden yedincisi ve sonuncusu motosiklet kullanıcılarının sürüş esnasında uyması gereken kurallar olarak ortaya çıkmıştır. Görüşmeler sonucunda ortaya çıkan kuralların tümü motosiklet kullanıcılarının güvenliklerini tehlikeye atmamaları için oluşturulan kurallar olarak ortaya çıkmıştır. Grup sürüşleri belli bir düzende (fermuar, çaprazlama, vb.), sürüş esnasında diğer motosiklet kullanıcılarını tehlikeye atmayacak şekilde gerçekleştirilmektedir Diğer taraftan motosikletlerde, diğer araçlarda olduğu gibi güvenliği sağlayacak donanımlar olmadığı için motosiklet kullanıcıları bu eksikliği giydikleri ayakkabı, dizlik, eldiven, ceket ve kask ile sağlamaktadırlar. Bu grupların önemli amaçlarından biri de yeni gelen grup üyelerine tam koruma ile motosiklet kullanmayı aşılamaktır. Bu nedenle birçok grupta donanım, özellikle kask olmadan motosiklet kullanılması yasaklanmıştır.

\section{SONUÇ VE TARTIŞMA}

Araştırma sonucunda motosiklet kullanıcılarının motosiklet gruplariyla seyahat etme ve gruplara katılma nedenleri güvenlik, sosyalleşme, tecrübe kazanma, deneyim paylaşma, eşitlik, grubun gücü ve grubun kuralları olarak ortaya çıkmıştır. Haslam ve arkadaşları (2009) sosyal grupların kişilerin hayatlarını çeşitli şekillerde zenginleştirdiğini ve kişilere, kişisel güvenlik, sosyal arkadaşlık, duygusal bağlanma, entelektüel uyarma ve iş birliğine dayalı öğrenme olanağı sağladıklarını belirtmektedir. Bu çalışmada, motosiklet kullanıcılarının motosiklet ile yalnız başlarına seyahatlerine göre grup seyahatinin daha güvenli olduğu, daha fazla keyif aldıkları, ortak bir tutkuyu paylaştıkları ve grubun gücünden etkilendikleri sonucuna ulaşılmıştır.

Motosiklet kullanıcılarının grup seyahatine katılmalarının en önemli nedeni güvenlik olarak ortaya çıkmıştır. Kişiler grup ile seyahat etmenin daha güvenli olduğunu ve yanlarında en az bir kişinin olmasının kendilerini güvende hissetmelerini sağladığını belirtmektedir. Broughton ve Walker (2009) motosiklet ile yalnız başına yapılan seyahatlere göre grup ile yapılan seyahatlerin daha güvenli olduğu sonucuna ulaşmıştır. Motosiklet grupları ile seyahatlerde grubun güvenliği- 
ni sağlayan kişilerin olması ve sürüş kurallarına uyulması gibi nedenlerle daha güvenli seyahat sağlanmaktadır.Haslam ve arkadaşları (2004) grubun üyelerinin, grubun dışındakiler yerine grubun içindeki kişilere daha fazla güvendiğini ifade etmektedir. Hornstein (1972) ise insanların grup içindeki diğer kişilere daha fazla yardım etmeye eğilimli olduklarını belirtmiştir. Motosiklet gruplarına katılan kişilerin de grup içindeki arkadaşlarına yüksek derecede güven ve bağlılık duygusunda olduğu sonucuna ulaşılmıştır. Aynı zamanda, motosiklet kullanıciları seyahat s1rasında yaşayacakları olumsuz durumların grup içinde çözülebileceğine inanmaktadır. Motosiklet kullanıcıları trafik içinde diğer kullanıcılar tarafından yaşadıkları sıkıştırma, taciz ve benzeri durumların grup içinde daha kalabalık oldukları için azaldığını düşünmektedirler. Clarke ve arkadaşları (2007) diğer araç kullanıcılarının trafikte motosiklet kullanıcılarını görmezden geldiğini ve bu durumun olası kazalara sebebiyet verdiğini belirtmektedir.

Motosiklet grupları kişinin sosyalleşmesinde önemli bir rol oynamaktadır. Yağmur ve Tarcanİçigen (2016) rekreasyon faaliyetlerinin, bireyin dinamik sosyal çevrelere katılımını sağlayan bir sosyal faaliyet olması özelliğinden dolayı kişinin sosyalleşmesini sağladığını ifade etmiştir. Motosiklet kullanıcıları gruba katıldıktan sonra yalnızlık duygularının ortadan kalktığını, daha fazla arkadaş edindiklerini ve seyahatlerinin daha keyifli hale geldiğini belirtmektedirler. Eren (1989) bir gruba üye olmanın ve grupta kabul edilmenin kişiyi yalnızlık duygusundan kurtardığını ifade etmektedir. Aynı zamanda grup içinde herkesin eşit haklara sahip olması motosiklet kullanıcılarını grupla seyahate yöneltmektedir. Grup içinde her kesimden ve meslekten kişinin olması, motosiklet kullanıcılarının sosyal çevresini genişletmekte ve daha fazla insan ile tanışmalarının yolunu açmaktadır.Ayrıca motosiklet grubundan önce az sayıda seyahat eden kişilerin grupla birlikte daha fazla seyahate katıldıkları sonucu ortaya çıkmıştır. Bunun yanında motosiklet kullanıcıları, motosikletle seyahat ettikleri zaman bir araya gelmelerinin haricinde günlük hayatlarında da sıklıkla görüştüklerini belirtmektedirler. Bazı motosiklet grupları haftada en az bir gün yaptıkları olağan grup toplantılarında görüştüklerini bazı gruplar ise haftanın belirli günlerinde en az bir kez bir araya gelerek etkinlikler yaptıklarını belirtmiştir.

Motosiklet grubunda kişiler ortak bir tutkuya sahip olduklarını ortak amaçları yerine getirmek için bir araya geldiklerini ifade etmektedir. Forsyth (2009) ile Johnson ve Johnson (2014) benzer şekilde kişilerin bir gruba üye olmalarının nedenleri arasında ortak amaçları yerine getirmek olduğunu belirtmektedir. Motosiklet kullanıcıları gruplarda ortak amaçları yerine getirmenin yanı sıra tek başına yapamayacakları ve deneyimleyemeyecekleri seyahatleri de grupla birlikte seyahat ederek gerçekleştirmektir. Sherif (1967) ve Turner da (1987) benzer şekilde kişilerin sosyal gruplarda tek başına gerçekleştiremeyeceği amaçları grup üyeliği sayesinde gerçekleştirebildiklerini ifade etmektedir. Grubun normal hayat açısından verdiği kazançlar da kişilerin grupla seyahat etmesini etkilemektedir. Motosiklet grubunun özellikle dışarıdaki kişiler üzerinde bir gösteriş sağlama ve farkındalık yaratmada önemli bir etkiye sahip olması kişilerin bu gruplara girmesine neden olmaktadır. Ayrıca, motosiklet grupları üyelerine kalabalığın verdiği güçle trafikte diğer araç sürücülerinin saygı duymasına, dışarıya verdikleri senkronize görüntüyle birlikte insanların ilgisini çekmesine neden olmaktadır. Bu şekilde motosiklet kullanıcıları daha fazla fark edildiklerini ve karşılaşılabilecek olumsuz durumları da en aza indirgediklerini düşünmektedirler.

Bu çalışma motosiklet kullanıcılarının gruplara üyelik ve bu gruplarla seyahat etmelerinin nedenlerini ortaya çıkarmak amacıyla yürütülmüştür. Rekreatif grup üyeliğinin nedenleri üzerine yapılan çalışmaların kısıtlı olması sebebiyle çalışmada alanyazın bölümünde konuya ilişkin bulgulara yer verilememiştir. Gruplar üzerine yapılan önceki çalışmalarda kişilerin gruplara dâhil olmalarının nedenleri arasında güvenlik, sosyal destek ve ortak amaçları yerine getirmek gibi nedenler bulunmuştur. Bu çalışmanın özelinde ise geçmiş çalışmalardan farklı olarak deneyim paylaşma, eşitlik ve grubun kuralları gibi durumlar motosiklet gruplarına katılma nedenleri olarak ortaya çıkmıştır. Diğer taraftan bu çalışma rek- 
reatif gruplar üzerine odaklanmaktadır; ancak çalışmada örneklem olarak sadece motosiklet grupları ele alınmış diğer rekreatif gruplar göz ardı edilmiştir. İleride dağcılık, doğa yürüyüşüu, bisiklet vb. gibi diğer rekreatif gruplar üzerine yapılacak çalışmalara katkı sağlanması amaçlanmıştır. Aynı zamanda rekreatif gruplar üzerine yapılacak benzer çalışmalarla ve grup dinamiği, grup üyeliği vb. konularda edinilen bilgilerle, bu grupları hedef kitle olarak belirleyen işletmelere önemli bilgiler sunabileceği düşünülmektedir. Ayrıca, motosiklet gruplarına üye olan kişilerin gruplarına aidiyet ve bağlllıklarının önemli derecede yüksek olduğu yapılan görüşmeler sırasında gözlemlenmiştir; ancak çalışmada bu duruma yer verilmemiştir. Özellikle yelekli ve yeleksiz motosiklet grupları arasında grup dinamiği, grup aidiyeti ve grup bağlılığ 1 gibi konularda önemli farklılıklar olabileceği görüşmeler sırasında ortaya çıkmıştır. Bu konular üzerinde ileride yapılacak çalışmalar rekreatif grup çalışmalarının zenginleşmesine olanak sağlayacaktır.

\section{KAYNAKÇA}

Allen, L. R. ve Donnelly, M. A. (1985). An Analysis of the Social Unit of Participation and the Perceived Psychological Outcomes Associated with most Enjoyable Recreation Activities, Leisure Sciences, 7 (4): 421- 441.

Anderson, C., John, O. P., Keltner, D. ve Kring, A. M. (2001). Who Attains Social Status? Effects of Personality and Physical Attractiveness in Social Groups, Journal of Personality and Social Psychology, 81 (1): 116- 132.

Atalay, A., Akbulut, A. K. ve Yücel, A. S. (2013). Bireylerin Sosyal Algı ve Sosyalleşme Düzeylerinin Gelişiminde Rekreasyonel Uygulamaların Önemi, Uluslararası Hakemli Aile Çocuk ve Eğitim Dergisi, 1 (1): 18-29.

Broughton, P. ve Walker, L. (2009). Motorcycling and Leisure Understanding the Recreational PTW Rider. New York: CRC Press.

Bucher, C. A. ve Bucher, R.D. (1974). Recreation for Today's Society. New Jersey: Frentice-Hall.

Can, E. (2015). Boş Zaman, Rekreasyon ve Etkinlik Turizmi İlişkisi, İstanbul Sosyal Bilimler Dergisi, Yaz (10): 1- 17.

Clarke, D. D., Ward, P., Bartle, C. ve Truman, W. (2007). The Role of Motorcyclist and Other Driver Behaviour in Two Types of Serious Accident in the UK, Accident Analysis \& Prevention, 39 (5): 974- 981.

Coleman, J. C. (1969). Psychology and Effective Behavior. Glenview: Scott Foresman and Company.

Creswell, J. W. (1998). Quality Inquiry and Research Design: Choosing among Five Traditions. Thousand Oaks, CA: Sage Yayınları.
Cruwys, T., Dingle, G. A., Haslam, C., Haslam, S. A., Jetten J. ve Morton T. A. (2013). Social Group Memberships Protect Against Future Depression, Alleviate Depression Symptoms and Prevent Depression Relapse, Social Science \& Medicine, 98: 179-186.

Eren, E. (1989). Yönetim Psikolojisi. İstanbul: İstanbul Üniversitesi Yayını.

Forsyth, D. R. (2009). Group Dynamics. ABD: Cengage Learning.

Guba, E. G. (1981). Criteria for Assessing the Trustworthiness of Naturalistic Inquiries, Educational Technology Research and Development, 29 (2): 75- 91.

Haslam, C., Holme, A., Haslam, S. A., Iyer, A., Jetten, J. ve Williams, W. H. (2008). Maintaining Group Memberships: Social Identity Continuity Predicts Well-Being after Stroke, Neuropsychological Rehabilitation, 18 (5-6): 671- 691.

Haslam, S. A., Jetten, J., O’Brien, A. ve Jacobs, E. (2004). Social Identity, Social Influence and Reactions to Potentially Stressful Tasks: Support for the Self-Categorization Model of Stress, Stress and Health, 20 (1): 3-9.

Haslam, S. A., Jetten, J., Postmes, T. ve Haslam, C. (2009). Social Identity, Health and Well-Being: An Emerging Agenda for Applied Psychology, Applied Psychology: An International Review, 58 (1): 1-23.

Hogg, M. A. ve Vaughan, G. M. (2007). Sosyal Psikoloji. 1. Baskı. Çevirenler: Aydın Gelmez ve İbrahim Yıldız. İstanbul: Ütopya Yayınevi.

Hornstein, H. A. (1972). Promotive Tension: The Basis of Prosocial Behavior from a Lewinian Perspective, Journal of Social Issues, 28 (3): 191- 218.

Johnson, D. W. ve Johnson, F. P. (2014). Joining Together: Group Theory and Group Skills. Edinburgh: Pearson.

Karaküçük, S. (2008). Rekreasyon Boş Zamanları Değerlendirme. 6. Bask1. Ankara: Gazi Kitabevi.

Kim, J. (2012). Exploring the Experience of Intergroup Contact and the Value of Recreation Activities in Facilitating Positive Intergroup Interactions of Immigrants, Leisure Sciences, 34 (1): 72- 87.

Mannering, F. L. ve Grodsky, L. L. (1995). Statistical Analysis of Motorcyclists' Perceived Accident Risk, Accident Analysis \& Prevention, 27 (1): 21-31.

Merriam, S. B. (2013). Nitel Araştırma. Çeviren: Selahattin Turan. Ankara: Nobel Akademik Yayıncılık.

Newman, B. M., Lohman, B. J. ve Newman, P. R. (2007). Peer Group Membership and a Sense of Belonging: Their Relationship to Adolescent Behavior Problems, Adolescence, 42 (166): 241-263.

Patton, M. Q. (2002). Qualitative Research \& Evaluation Methods. Kaliforniya: Sage Publications.

Reicher, S. ve Haslam, S. A. (2006). Tyranny Revisited Groups, Psychological Well-Being and the Health of Societies, The Psychologist, 19 (3): 146-150.

Shenton, A. K. (2004). Strategies for Ensuring Trustworthiness in Qualitative Research Projects, Education for Information, 22: 63-75.

Sherif, M. (1936). The Psychology of Social Norms. Oxford, İngil- 
tere: Harper \& Bros.

Sherif, M. (1967). Group Conflict and Co-Operation: Their Social Psychology. Londra: Psychology Press.

Strauss, A. ve Corbin, J. (1990). Basics of Qualitative Research: Grounded Theory Procedurs and Techniques. Kaliforniya: Sage Yayınları.

Swann, Jr., W. B., Jetten, J., Gómez, Á. Whitehouse, H. ve Bastian, B. (2012). When Group Membership Gets Personal: A Theory of Identity Fusion, Psychological Review, 119 (3): 441- 456

Tajfel, H. (1970). Experiments in Intergroup Discrimination, Scientific American, 223 (5): 96- 103.

Tajfel, H. (1978). Differentiation between Social Groups: Studies in the Social Psychology of Inter-Group Relations. Londra: Academic Press.

Tajfel, H. (1981). Human Groups and Social Categories: Studies in Social Psychology. New York: Cambridge Üniversitesi Yayınları.

Tel, M. ve Köksalan, B. (2008). Öğretim Üyelerinin Spor Etkinliklerinin Sosyolojik Olarak İncelenmesi (Doğu Anadolu Örneği), Firat Üniversitesi Sosyal Bilimler Dergisi, 18 (1): 261-278.
Turner, J. C. (1987). Rediscovering the Social Group: A SelfCategorization Theory. New York: Basil Blackwell.

Turner, J. C., Reynolds, K. J., Haslam, S. A. ve Veenstra, K. E. (2006). Reconceptualizing Personality: Producing Individuality by Defining the Personal Self. İçinde T. Postmes ve J. Jetten (Editörler), Individuality and the Group: Advances in Social Identity (ss. 11-36). Londra: Sage Yayınları.

Tütüncü, Ö. (2012). Rekreasyon ve Rekreasyon Terapisinin Yaşam Kalitesindeki Rolü, Anatolia: Turizm Araştırmalarl Dergisi, 23 (2): 248- 252.

Tütüncü, Ö. ve Aydın, G. (2014). Toplum ve Açık Hava Rekreasyon Faaliyetleri: ABD Örneği, Anatolia: Turizm Araştırmaları Dergisi, 25 (1): 118- 120.

Van Knippenberg, D., Van Knippenberg, B., Monden, L. ve De Lima, F. (2002). Organizational Identification after a Merger: A Social Identity Perspective, British Journal of Social Psychology, 41 (2): 233- 252.

Yağmur, Y. ve Tarcan-İçigen, E. (2016). Üniversite Öğrencilerinin Sosyalleşme Süreci ve Rekreasyon Faaliyetlerinin İncelenmesi Üzerine Bir Çalışma, Anatolia: Turizm Araştırmaları Dergisi, 27 (2): 227- 242.

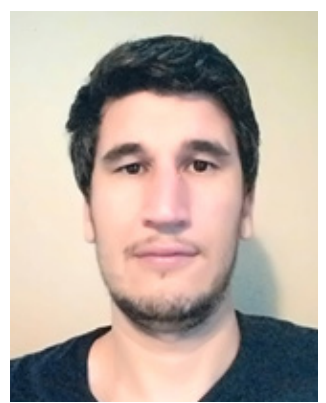

Mehmet ERTAŞ

Çukurova Üniversitesi Turizm İşletmeciliği ve Otelcilik Yüksekokulu Konaklama İşletmeciliği Bölümü’nden mezun oldu (2011). Yüksek lisans derecesini Dokuz Eylül Üniversitesi Turizm İşletmeciliği Dalı’ndan aldı (2014). Doktora derecesini de Dokuz Eylül Üniversitesi Turizm işletmeciliği Bölümü'nden aldı (2019). Pamukkale Üniversitesi'nde çalışmaya başladı (2012). 35. madde ile Dokuz Eylül Üniversitesi İşletme Fakültesi Turizm İşletmeciliği Bölümü'nde çalışmaya başladı (2013). Halen Pamukkale Üniversitesi Turizm Fakültesi Turizm İşletmeciliği Bölümü’nde görev yapmaktadır. Temel çalışma alanları, turizm pazarlaması, destinasyon pazarlaması ve rekreasyondur.

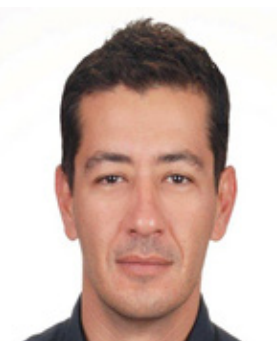

\section{Gürhan AKTAŞ}

Hacettepe Üniversitesi IïBF Fakültesi İşletme Bölümü'nden mezun oldu (1992). Yüksek lisans derecesini Surrey Üniversitesi'nden Turizm İşletmeciliği Dalı'ndan (1995), doktora derecesini de Bournemouth Üniversitesi'nden Turizm İşletmeciliği Dalı'ndan aldı (2006). Dokuz Eylül Üniversitesi'nde çalışmaya başladı (1994). Doçentlik unvanını Turizm alanında aldı (2014). Halen Dokuz Eylül Üniversitesi İşletme Fakültesi Turizm İşletmeciliğ Bölümü'nde görev yapmaktadır. Temel çalışma alanı, turizm pazarlamasıdır. 